\title{
Vascular Defense Responses in Rice: Peroxidase Accumulation in Xylem Parenchyma Cells and Xylem Wall Thickening
}

\author{
Emmanuel Hilaire, ${ }^{1}$ Scott A. Young, ${ }^{1}$ Lloyd H. Willard, ${ }^{2}$ J. David McGee, ${ }^{1}$ Teresa Sweat, ${ }^{1}$ \\ J. M. Chittoor, ${ }^{1}$ James A. Guikema, ${ }^{3}$ and Jan E. Leach ${ }^{1}$ \\ 'Department of Plant Pathology, 4024 Throckmorton Plant Sciences Center, Kansas State University, \\ Manhattan 66506-5502, U.S.A.; ${ }^{2}$ College of Veterinary Medicine, Department of Diagnostic Medicine and \\ Pathobiology, Kansas State University, Manhattan 66506-5614, U.S.A.; ${ }^{3}$ Division of Biology, Ackert Hall, \\ Kansas State University, Manhattan 66506-4901, U.S.A. \\ Submitted 14 June 2001; Accepted 31 August 2001.
}

The rice bacterial blight pathogen Xanthomonas oryzae pv. oryzae is a vascular pathogen that elicits a defensive response through interaction with metabolically active rice cells. In leaves of 12-day-old rice seedlings, the exposed pit membrane separating the xylem lumen from the associated parenchyma cells allows contact with bacterial cells. During resistant responses, the xylem secondary walls thicken within $48 \mathrm{~h}$ and the pit diameter decreases, effectively reducing the area of pit membrane exposed for access by bacteria. In susceptible interactions and mock-inoculated controls, the xylem walls do not thicken within $48 \mathrm{~h}$. Xylem secondary wall thickening is developmental and, in untreated 65-day-old rice plants, the size of the pit also is reduced. Activity and accumulation of a secreted cationic peroxidase, $\mathrm{PO}-\mathrm{C} 1$, were previously shown to increase in xylem vessel walls and lumen. Peptide-specific antibodies and immunogold-labeling were used to demonstrate that PO-C1 is produced in the xylem parenchyma and secreted to the xylem lumen and walls. The timing of the accumulation is consistent with vessel secondary wall thickening. The $\mathrm{PO}-\mathrm{Cl}$ gene is distinct but shares a high level of similarity with previously cloned pathogen-induced peroxidases in rice. $\mathrm{PO}-\mathrm{Cl}$ gene expression was induced as early as $12 \mathrm{~h}$ during resistant interactions and peaked between 18 and $24 \mathrm{~h}$ after inoculation. Expression during susceptible interactions was lower than that observed in resistant interactions and was undetectable after infiltration with water, after mechanical wounding, or in mature leaves. These data are consistent with a role for vessel secondary wall thickening and peroxidase $\mathrm{PO}-\mathrm{C1}$ accumulation in the defense response in rice to $X$. oryzae pv. oryzae.

Additional keywords: lignification, pit aperture.

Corresponding author: Jan E. Leach; E-mail: jeleach@ksu.edu

Current address for Emmanuel Hilaire: National Jewish Medical and Research Center, 1400 Jackson Street, Denver, CO 80206 U.S.A.

Current address for Scott A. Young: The Dow Chemical Company, Analytical Sciences, 1897 Building, Midland, MI 48667 U.S.A.

Current address for J. M. Chittoor: Monsanto Company, 800 North Lindberg Boulevard, St. Louis, MO 63167 U.S.A.
Considerable progress has been made in understanding events involved in the activation of plant defense responses by bacterial pathogens (Galan and Collmer 1999). Based on the best characterized of these interactions, contact between the bacterium and a metabolically active leaf mesophyll cell is predicted to be required for transfer of avirulence signals from the pathogen to the host cell and the induction of resistance. The xylem vessels of plants offer a particularly hospitable environment for plant pathogens. In fact, several important bacterial pathogens, including the rice bacterial blight pathogen Xanthomonas oryzae pv. oryzae, remain within xylem vessels throughout the disease interaction (Goodman et al. 1986; Tabei 1967). During its existence in the xylem vessel, the pathogen's contact with living cells, i.e., the xylem parenchyma, occurs at the pit membranes. The pit membranes, consisting of the primary wall of the parenchyma cell, the pectinaceous middle lamella, and the primary cell wall of the tracheary cell, are more complex than the walls of mesophyll cells.

Xylem parenchyma cells adjacent to fungal-infected xylem vessels have been reported to undergo drastic metabolic changes, including the production of callose, chitinase, and ligninlike compounds (Beckman et al. 1991; Benhamou 1995; Mueller et al. 1994; Shi et al. 1992). Only limited information, however, is available on the changes occurring in the xylem and xylem parenchyma during interactions with bacterial pathogens (Goodman et al. 1986; Horino 1976, 1981; Horino and Kaku 1989; Sequeira et al. 1977).

Ultrastructural analyses of interactions between rice (Oryza sativa) and $X$. oryzae pv. oryzae show bacterial multiplication in the vessels in both compatible and incompatible interactions (Horino 1976, 1981; Horino and Kaku 1989). In the incompatible interactions, $X$. oryzae pv. oryzae cells within rice vessels were irregular in shape and were enveloped by abundant fibrillar material after 3 days. In contrast, during the compatible interactions, bacterial cells appeared normal and were not surrounded by the fibrillar material until after 20 days (Horino 1976, 1981). Using an inoculation technique that distributed bacteria predominantly into the leaf mesophyll, Reimers and coworkers (Guo et al. 1993; Reimers and Leach 1991; Reimers et al. 1992) demonstrated that incompatible interactions were characterized by the accumulation of lignin polymers in the cell walls and the increased activity of three 
isozymes of peroxidase (two anionic and one cationic) in the apoplast of leaf parenchyma. The pattern of accumulation and cellular location of PO-C1, a cationic pathogen-induced peroxidase, was determined using domain-specific antibodies (Young et al. 1995). PO-C1 was detected in the cell walls and extracellular spaces in leaf mesophyll tissues and in the vessel lumen and walls of xylem elements within $12 \mathrm{~h}$ after inoculation with avirulent strains of $X$. oryzae pv. oryzae (Young et al. 1995). Based on the temporal and spatial patterns of activity and accumulation and on the substrate utilization pattern of the isoenzyme, $\mathrm{PO}-\mathrm{C} 1$ was predicted to contribute to the rice defense response (Reimers et al. 1992; Young et al. 1995).

Induction of peroxidase genes, enzyme activity, or both, has been linked with disease resistance in many plant species
(Chittoor et al. 1999; Kristensen et al. 1999). However, precisely how the peroxidases participate in the defense response is not clear, but a variety of roles have been proposed (Bradley et al. 1992; Moerschbacher 1992; Mohan and Kolattukudy 1990; Ride 1983). One possible role for peroxidases is the formation of structural barriers such as cell wall enhancement and deposition of cell wall appositions, both of which can involve the polymerization of lignin or suberin (Hammerschmidt and Kuc 1982; Espelie et al. 1986), the cross-linking of wall glycoproteins or polysaccharides (Bradley et al. 1992; Fry 1986; Iiyama et al. 1994), and the dimerization of antimicrobial phenols (Ikegawa et al. 1996; Stoessl 1967). Another possibility is that the free radical intermediates produced by peroxidase-oxidative activity are toxic to the pathogens (Martinez et al. 2000; Sutherland 1991).
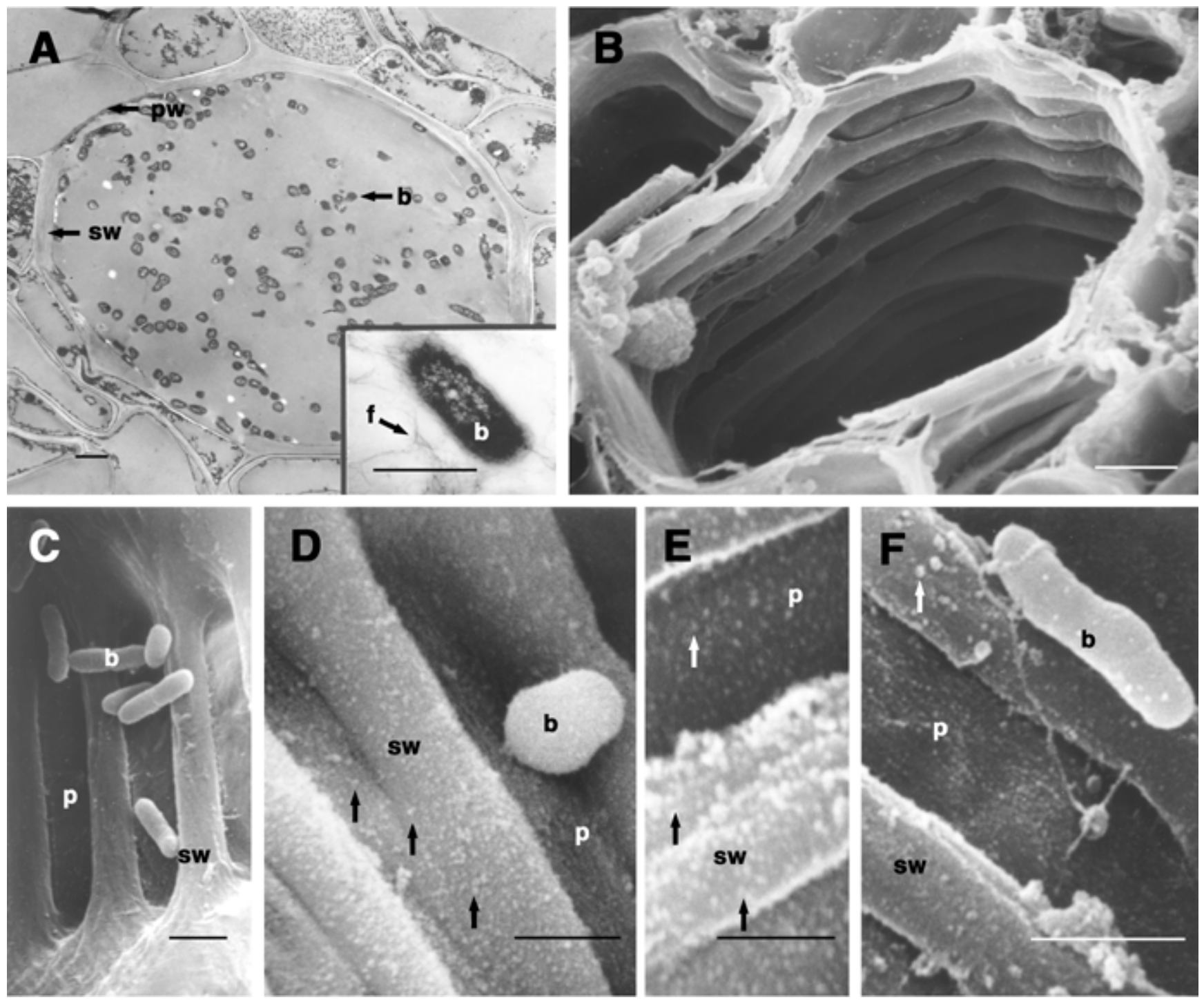

Fig. 1. A,Transmission electron microscopy (TEM) images and, (B to F) scanning electron microscopy (SEM) images of rice leaf tissue infiltrated with avirulent and virulent strains of Xanthomonas oryzae pv. oryzae. A, X. oryzae pv. oryzae strain PXO99 ${ }^{\mathrm{A}}(\mathrm{pBUavrXa10.F1)}$ cells within a xylem vessel in 'IRBB10' (incompatible interaction); inset, a bacterial cell with associated fibrillar material. B, Xylem vessel and associated parenchyma with connecting pits in an uninfected 'IRBB10' 12-day-old rice leaf. C, X. oryzae pv. oryzae strain PXO99A (pBUavrXa10.F1) cells in the apertures of pits of a xylem vessel of 'IRBB10' (incompatible interaction). D and E, PO-C1 location (arrows) during incompatible ('IRBB10') interactions $24 \mathrm{~h}$ after infiltration with $X$. oryzae pv. oryzae strain PXO99 (pBUavrXa10.F1). F, PO-C1 location (arrows) during a compatible interaction $24 \mathrm{~h}$ after infiltration with X. oryzae pv. oryzae strain $\mathrm{PXO} 99^{\mathrm{A}}(\mathrm{pHM} 1)$. Bar $=3 \mu \mathrm{m}$; b, bacteria; f, fibrillar material; $\mathrm{p}$, pit aperture; pw, primary wall; and sw, secondary wall. 
In this study, we focused on two resistance-associated events during the interactions of rice with $X$. oryzae pv. oryzae: the ultrastructural changes in xylem secondary walls and xylem parenchyma cells, and the correlated changes in $\mathrm{PO}-\mathrm{Cl}$ gene induction and isoenzyme location. We show that xylem secondary walls thicken during incompatible interactions and that this thickening effectively reduces the exposure of the pit membrane to the bacterial pathogen. These changes correlate with the accumulation of cationic peroxidase PO-C1 in xylem parenchyma and in the vessel walls and lumen. The $P O-C l$ gene was cloned and characterized and shown to be transiently induced between 12 and $48 \mathrm{~h}$ postinoculation during the incompatible interactions.

\section{RESULTS}

\section{Ultrastructural changes in xylem and xylem parenchyma} during incompatible interactions.

Transmission electron microscopy (TEM) images revealed that xylem vessels at the inoculation site were filled with bacteria in both incompatible (Fig. 1A) and compatible interactions (data not shown) by $24 \mathrm{~h}$ postinoculation. In incompatible, but not compatible, interactions, fibrillar material was observed around the bacteria within the vessel at $24 \mathrm{~h}$ (Fig. $1 \mathrm{~A}$, inset), and the presence of organellar remains in the cytoplasm (data not shown) suggests xylem parenchyma cells were degraded. In contrast, during the compatible interactions and in the water-infiltrated control, vascular parenchyma cells displayed a well-preserved ultrastructure with intact organelles (data not shown). Bacteria were never observed within the xylem parenchyma in any treatment at any time.

Scanning electron microscopy (SEM) of 12-day-old rice seedlings was used to study the consequences of interactions occurring within the xylem vessels. In 12-day-old rice seedlings, pits separating the xylem parenchyma and the xylem element are the prominent feature within the vessels (Fig. 1B). In both incompatible and compatible interactions (Fig. 1C to F), bacteria were frequently associated with the pit membranes.

Measurements of the diameter of the pit and the width of the secondary xylem walls from the SEM study were used to quantify xylem secondary wall thickening in rice seedlings during interactions with $X$. oryzae pv. oryzae and in mockinoculated controls (Table 1). At $3 \mathrm{~h}$ postinoculation, no differences were observed in the diameter of pits after treatment with either the virulent or avirulent $X$. oryzae pv. oryzae strains or the mock-inoculated rice control. However, by $48 \mathrm{~h}$ postinoculation, the secondary walls of the xylem vessels in incompatible interactions were thickened relative to the $3 \mathrm{~h}$ time point, the compatible interaction, and the mock-inocu-
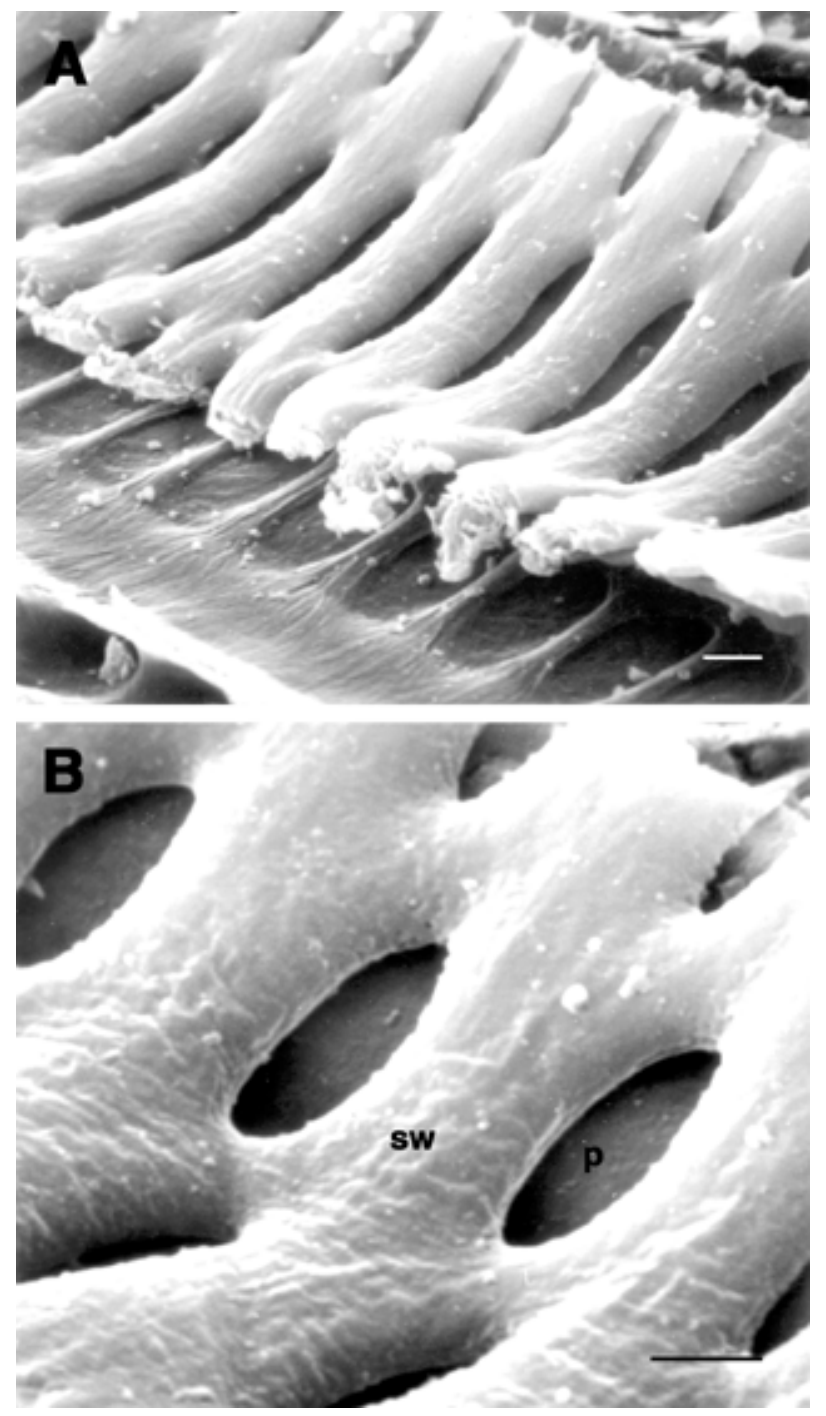

Fig. 2. A, Longitudinal section of a xylem vessel from a noninoculated 65-day-old 'IRBB10' rice leaf viewed by scanning electron microscopy. B, Higher magnification showing the aperture of the pits (average diameter of short axis $=2.1 \mu \mathrm{m} \pm 0.5$ ) and the thickened secondary walls (average distance between aperture at short axis $=7.4 \mu \mathrm{m} \pm 0.5$ ). Bar $=$ $3 \mu \mathrm{m} ; \mathrm{p}$, pit; and sw, secondary wall.

Table 1. Mean size ( $\mu \mathrm{m} \pm$ standard error) of rice xylem vessel secondary wall and pit aperture changes during incompatible, but not compatible, interactions with Xanthomonas oryzae pv. oryzae $e^{\mathrm{y}}$

\begin{tabular}{|c|c|c|c|c|c|c|}
\hline \multirow[b]{3}{*}{ Rice cultivar } & \multirow{3}{*}{$\begin{array}{l}X . \text { oryzae pv. orzyae } \\
\text { strain or treatment }\end{array}$} & \multirow[b]{3}{*}{ Interaction } & \multicolumn{4}{|c|}{ Mean size of changes } \\
\hline & & & \multicolumn{2}{|c|}{ Secondary wall } & \multicolumn{2}{|c|}{ Pit aperture } \\
\hline & & & $3 \mathrm{~h}$ & $48 \mathrm{~h}$ & $3 \mathrm{~h}$ & $48 \mathrm{~h}$ \\
\hline IRBB 10 & $\begin{array}{l}\text { Mock inoculation } \\
\text { PXO99 }(\text { pHMI) } \\
\text { PXO99 }(\text { pBUavrXa10.F1) }\end{array}$ & $\begin{array}{l}\text { Compatible } \\
\text { Incompatible }\end{array}$ & $\begin{array}{l}4.7 \pm 0.1 \mathrm{a}^{\mathrm{z}} \\
4.8 \pm 0.1 \mathrm{a} \\
4.8 \pm 0.2 \mathrm{a}\end{array}$ & $\begin{array}{l}4.8 \pm 0.1 \mathrm{a} \\
4.8 \pm 0.1 \mathrm{a} \\
5.8 \pm 0.1 \mathrm{~b}\end{array}$ & $\begin{array}{l}4.6 \pm 0.1 \mathrm{a} \\
4.7 \pm 0.1 \mathrm{a} \\
4.7 \pm 0.1 \mathrm{a}\end{array}$ & $\begin{array}{l}4.7 \pm 0.2 \mathrm{a} \\
4.7 \pm 0.2 \mathrm{a} \\
3.8 \pm 0.1 \mathrm{~b}\end{array}$ \\
\hline IR24 & $\begin{array}{l}\text { Mock inoculation } \\
\text { PXO99 }(\mathrm{pBUavrXa10.F1)}\end{array}$ & $\begin{array}{l}\ldots \\
\text { Compatible }\end{array}$ & $\begin{array}{l}5.2 \pm 0.2 \mathrm{a} \\
5.3 \pm 0.1 \mathrm{a}\end{array}$ & $\begin{array}{l}5.4 \pm 0.2 \mathrm{a} \\
5.3 \pm 0.3 \mathrm{a}\end{array}$ & $\begin{array}{l}5.6 \pm 0.4 \mathrm{a} \\
5.7 \pm 0.4 \mathrm{a}\end{array}$ & $\begin{array}{l}5.4 \pm 0.3 \mathrm{a} \\
5.7 \pm 0.3 \mathrm{a}\end{array}$ \\
\hline
\end{tabular}

${ }^{y}$ Secondary wall thickness and pit aperture size were measured on the short axis of the elipse in scanning electron microscopy photos as described in text. Experiments with 'IRBB10' and 'IR24' were performed at two different times. Each experiment was repeated, with similar results.

${ }^{\mathrm{z}}$ Mean thickness or size within a cell structure with the same letter are not different in that particular cultivar according to least squares means at $P=0.01$. 
lated control (Table 1). As a consequence of secondary wall thickening, the diameter of the pit was reduced in incompatible interactions relative to the other treatments.

To determine if cell wall thickening could be induced by AvrXa10 in the absence of the Xal0 gene product in rice, cultivar IR24, which does not contain Xa10, was inoculated with $X$. oryzae pv. oryzae containing avrXa10. No wall thickening was observed in the treated versus control tissues, suggesting that AvrXa10 does not cause thickening in the absence of recognition by the XalO product (Table 1 ).

Since mature rice plants are more resistant to bacterial blight than young seedlings are, we wondered if pits of mature (65-day-old) plants could accommodate bacterial cells. We observed that secondary xylem wall thickening and the reduction in diameter of the pit are also consequences of development in rice (Fig. 2A and B). The pit diameters in mature rice vessels were even smaller than those observed in incompatible interactions, averaging $2.1 \mu \mathrm{m} \pm 0.5$ ( \pm standard error [SE]).
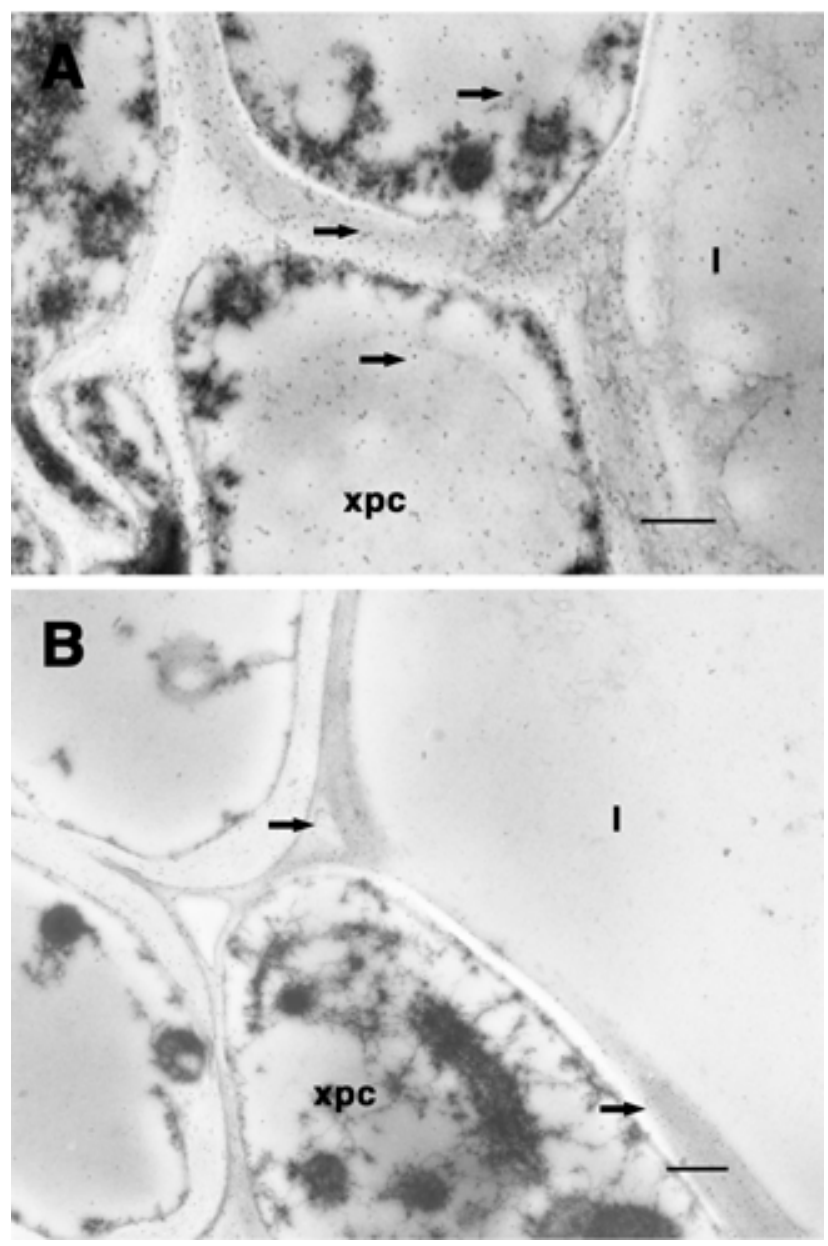

Fig. 3. Immunolocalization of $\mathrm{PO}-\mathrm{C} 1$ in rice xylem parenchyma cells infiltrated with Xanthomonas oryzae pv. oryzae observed by transmission electron microscopy. Images show PO-C1 location during compatible ('IR24') and incompatible ('IRBB10') interactions at $24 \mathrm{~h}$ after infiltration with PXO99 ${ }^{\mathrm{A}}$ (pBUavrXa10.F1). A, Xylem parenchyma cell in 'IRBB10' during an incompatible interaction. B, Xylem parenchyma cell in 'IR24' during a compatible interaction. A and B, Rice tissue was probed with peptide-specific anti-PO-C1 antibodies and detected with gold-labeled Protein-A. The arrows indicate PO-C1- associated gold particles. Bar = $2 \mu \mathrm{m} ; 1$, lumen; and xpc, xylem parenchyma cell.
The secondary wall thickness in mature vessels was $7.4 \mu \mathrm{m}+$ $0.6( \pm \mathrm{SE})$.

\section{Localization of PO-C1}

in xylem and xylem parenchyma cells.

Domain-specific antibodies were previously generated to a synthetic peptide (MNLAMNLAPLD) that included a region (MNLAPLD) of the cationic peroxidase PO-C1 that diverged from other plant peroxidases (Young et al. 1995). Immunogold-labeling analysis using affinity-purified anti-PO-C1 antibody showed many PO-C1-associated gold particles were present on the pit membranes and secondary walls of the xylem in incompatible interactions (Figs. 1D and E and 3A) at $24 \mathrm{~h}$ postinoculation, whereas few particles were observed in xylem during compatible interactions (Figs. 1F and 3B).

The anti-PO-C1 antibodies were used to determine if PO$\mathrm{C} 1$ accumulated in xylem parenchyma (Fig. 3A and B) and to quantitate the subcellular localization of PO-C1 at 3, 12, and $24 \mathrm{~h}$ after infection in rice undergoing incompatible or compatible interactions with $X$. oryzae pv. oryzae (Fig. 4). More gold particles associated with PO-C1 were detected $24 \mathrm{~h}$ after infection during incompatible interactions (Figs. 1D and $\mathrm{E}$ and $3 \mathrm{~A}$ and 4) than during compatible interactions (Figs. 1F, 3B, and 4). The gold particles associated with PO-C1 were found in the xylem walls and lumen (Young et al. 1995) (Figs. 3A and 4) and, in addition, in the walls of the xylem parenchyma (Figs. 3A and 4). These gold particles were distributed along both secondary and primary walls of the xylem parenchyma and, of relevance to this study, were clearly observed in the thinned primary walls of the pit membranes.

Quantitation of the gold particles over time showed a gradual increase within the cytoplasm and the primary and secondary walls of xylem parenchyma cells during the incompatible interactions (Fig. 4). At 3 h, very few gold particles were associated with the cell walls in either kind of interaction. No differences in the number of gold particles were detected in the plasma membrane and organelles (data not shown). In contrast, no accumulation of gold particles was observed in the xylem parenchyma cells or walls during compatible interactions at any of the three time points (Fig. 4). In this treatment,

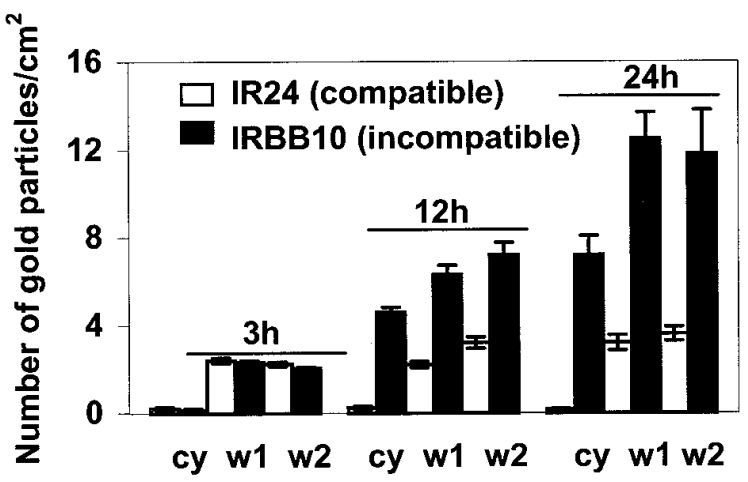

Fig. 4. Location of PO-C1 in xylem parenchyma and xylem vessels of rice tissues during incompatible ('IRBB10', dark bars) and compatible ('IR24', white bars) interactions at 3, 12, and $24 \mathrm{~h}$ postinoculation with Xanthomonas oryzae pv. oryzae PX099 (pBUavrXa10.F1). The mean number of $\mathrm{PO}-\mathrm{C} 1-$ associated particles per square centimeter are reported for each cellular location. Cellular locations indicated are cy, cytoplasm; w1, primary cell wall; and w2, secondary cell wall. 
little labeling was detected in the cytoplasm, vacuoles, plasma membrane, or walls of xylem parenchyma cells.

\section{$P O-C 1$ gene and amino acid sequence analysis.}

The genomic copy of $\mathrm{PO}-\mathrm{Cl}$ was cloned by inverse polymerase chain reaction, and the $P O-C l \mathrm{cDNA}$ was identified from a cDNA library constructed from rice undergoing a resistant interaction with $X$. oryzae pv. oryzae at $12 \mathrm{~h}$ postinoculation. Both were sequenced and used to deduce the $\mathrm{PO}-\mathrm{Cl}$ gene and protein primary structure. The $1.3-\mathrm{kb} P O-C l$ gene (GenBank accession no. AF247700) contains three introns and a 297-bp 3' untranslated region (UTR). The putative PO-C1 protein contains 313 amino acids and has an estimated molecular weight of $32.6 \mathrm{kDa}$ before glycosylation (Peptidesort; Genetic Computer Group, Madison, WI, U.S.A.). A predictedsignal peptide cleavage site is located between amino acids 23 and 24 (SignalP; Center for Biological Sequence Analysis, Lyngby, Denmark) (Fig. 5). The PO-C1 amino acid sequence is distinct but is highly similar to two previously cloned (Chittoor et al. 1997) rice peroxidases (70\% similar to POX8.1 and $75 \%$ similar to POX22.3) (Fig. 5).

The PO-C1 sequence contains MNAPLD, the peptide that was previously chosen, based on partial protein sequencing, for the production of the $\mathrm{PO}-\mathrm{C} 1$-specific antibody (Young et al. 1995). This peptide sequence was not found in POX8.1, POX22.3 (Fig. 5), or any other reported rice or plant peroxidase.

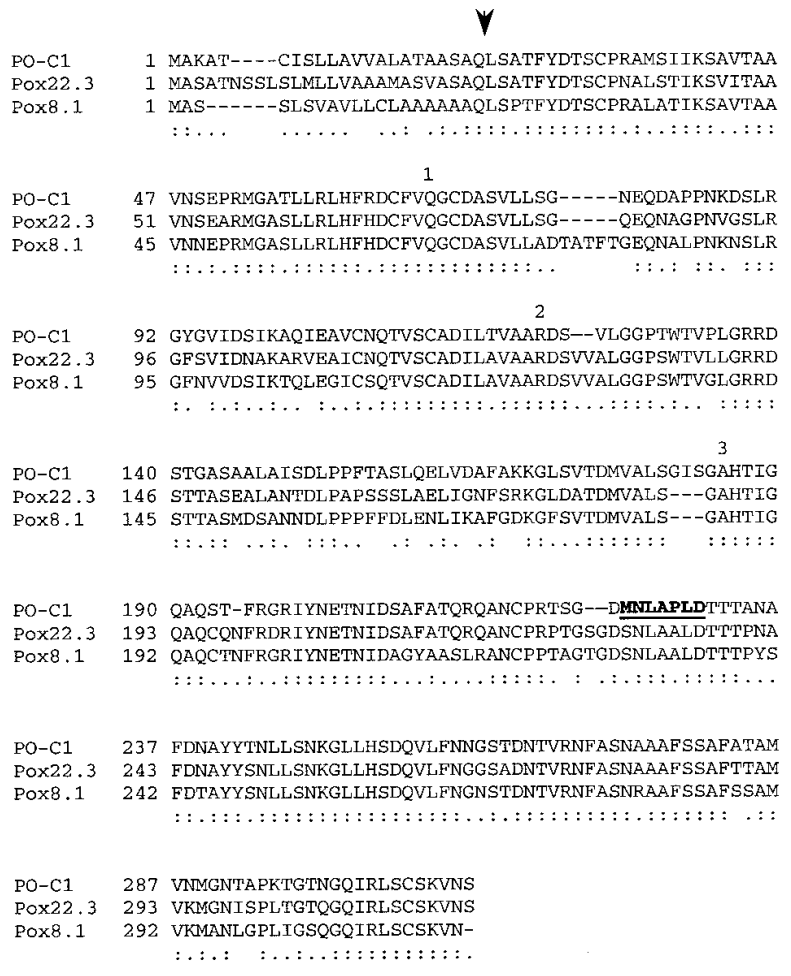

Fig. 5. Comparison of the deduced PO-C1 amino acid sequence with those of two pathogen-inducible rice peroxidases (POX8.1 and POX22.3). Bold and underline indicates the amino acids used to generate peptidespecific antibodies (MNLAPLD). The arrow shows a predicted-signal peptide cleavage site between amino acids 23 and 24. Numerals 1,2 , and 3 refer to the location of introns, ":" indicates all three amino acids are the same, and "." indicates two of the three peroxidases contain the same amino acid.
DNA blot analysis of rice DNA, digested with different restriction enzymes and probed with either the first intron region or the $3^{\prime}$ UTR of $P O-C l$, was used to estimate the copy number of $\mathrm{PO}-\mathrm{Cl}$ in the rice genome. The $\mathrm{PO}-\mathrm{Cl}$ intron-specific probe hybridized to a single fragment after digestion with HindIII and XmnI, HindIII and NheI, HindIII and BamHI, BamHI and XmnI, and BamHI and NheI (Fig. 6). Similarly, the $3^{\prime}$ UTR of $P O-C 1$ hybridized to only a single fragment in rice DNA digested with EcoRI, EcoRV, HindIII, XbaI, and $\mathrm{DraI}$. These results suggest that the $\mathrm{PO}-\mathrm{Cl}$ gene exists as a single copy in the rice genome.

\section{$P O-C 1$ gene induction.}

RNA blot analyses, using the $3^{\prime}$ UTR of $P O-C 1$ as a probe, demonstrated that induction of $\mathrm{PO}-\mathrm{Cl}$ occurred as early as $12 \mathrm{~h}$ postinoculation during the incompatible interactions, with maximum expression at $18 \mathrm{~h}$ postinoculation (Fig. 7). Little to no $\mathrm{PO}-\mathrm{Cl}$ transcript was detected at $48 \mathrm{~h}$ (Fig. 7), and no tran-

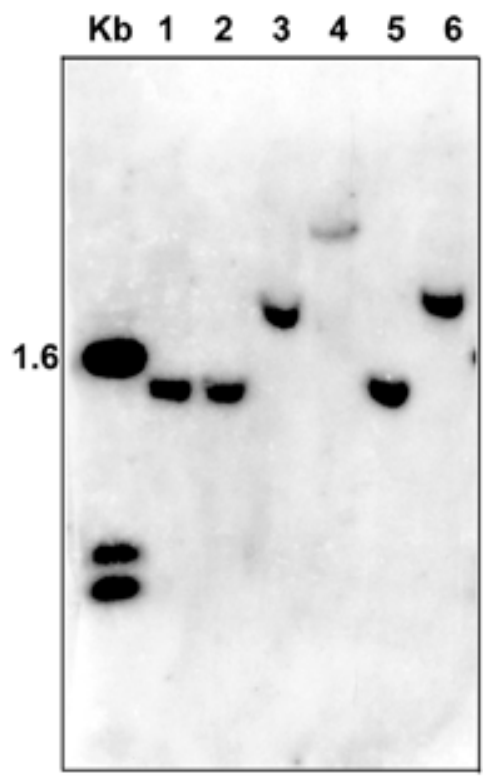

Fig. 6. DNA blot analysis of genomic DNA from rice cultivar IRBB10 hybridized with a gene-specific probe for $\mathrm{PO}-\mathrm{Cl}$. The DNA was digested with NheI and XmnI (lane 1), HindIII and XmnI (lane 2), HindIII and NheI (lane 3), HindIII and BamHI (lane 4), BamHI and XmnI (lane 5), and BamHI and NheI (lane 6).

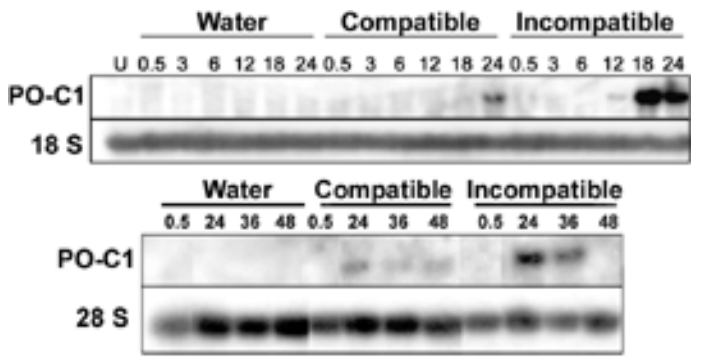

Fig. 7. RNA blot analysis of $\mathrm{PO}-\mathrm{Cl}$ gene induction pattern after inoculation of 'IRBB10' leaves with the virulent Xanthomonas oryzae pv. oryzae strain $\mathrm{PXO}^{\mathrm{A}}(\mathrm{pBU})$ (compatible) or the avirulent strain $\mathrm{PXO} 99^{\mathrm{A}}$ (pBUavrXa10) (incompatible). RNA was extracted from rice leaves harvested at $0.5,3,6,12,18$, and $24 \mathrm{~h}$ (upper blot) and $0.5,24$, 36 , and $48 \mathrm{~h}$ (lower blot) after infiltration with $X$. oryzae pv. orzyae. Control leaves were either untreated (U) or infiltrated with water (Water). Equal loading was assessed using $18 \mathrm{~S}$ or $28 \mathrm{~S}$ rRNA probes. 
script was detected at $72 \mathrm{~h}$ (data not shown). During the compatible interactions, $\mathrm{PO}-\mathrm{Cl}$ expression was barely detected after $18 \mathrm{~h}$, weak expression was observed to $48 \mathrm{~h}$ (Fig. 7), and no transcript was detected at $72 \mathrm{~h}$ postinoculation (data not shown). No $\mathrm{PO}-\mathrm{Cl}$ transcript was detected in water controls. $\mathrm{PO}-\mathrm{Cl}$ expression was only detected in pathogen-treated leaves; expression was not detected in mechanically wounded leaves or in roots or leaves of 1- or 3-month-old plants (data not shown).

\section{DISCUSSION}

The rice bacterial blight pathogen $X$. oryzae pv. oryzae is primarily a vascular pathogen that elicits a defensive response through interaction with metabolically active rice cells. Using ultrastructural analyses, we show that the pathogen contacts the xylem parenchyma cells bordering the vessel, and that this contact has several consequences that are specific to the incompatible interactions. Within $12 \mathrm{~h}$ of inoculation, expression of a defense-specific peroxidase gene $P O-C l$ is induced, and the enzyme accumulates in the xylem parenchyma cells and in the xylem vessel lumen and walls. The xylem secondary walls thicken, reducing the pit diameter and effectively reducing access of bacterial cells to the living parenchyma cells.

A number of biochemical and ultrastructural responses of xylem parenchyma cells proximal to infected xylem vessels have been previously reported (Beckman et al. 1991; Benhamou 1995; Mueller et al. 1994; Shi et al. 1991). For example, Benhamou (1995) reported a cytoplasmic reorganization in paratracheal parenchyma cells adjacent to infected xylem vessels, and Shi and associates (1992) described an increase in cytoplasmic content and activity in cells in contact with infected vessels. In our study, significant ultrastructural changes observed during the incompatible interactions included cytoplasmic degradation in the xylem parenchyma cells within $24 \mathrm{~h}$ of inoculation and thickening of the xylem secondary walls with a reduction in pit diameter by $48 \mathrm{~h}$ postinoculation.

Concomitant with the ultrastructural changes, we observed that cationic peroxidase PO-C1 accumulated in the cytoplasm, the primary and secondary walls of the xylem parenchyma, and the secondary walls and lumen of the xylem cells as early as $12 \mathrm{~h}$ after infection during incompatible interactions. Significant levels of PO-C1 were not detected in the cytoplasm or walls of xylem parenchyma cells undergoing compatible interactions. In addition, immunogold-labeling analysis revealed that PO-C1 accumulated in the cytoplasm and cell walls of xylem parenchyma cells surrounding infected xylem vessels during incompatible interactions with $X$. oryzae pv. oryzae. These data are consistent with an induced expression of the isoenzyme in the xylem parenchyma cells and the subsequent distribution into the enucleated xylem vessels.

Both the genomic DNA and cDNA copies of $\mathrm{PO}-\mathrm{Cl}$ were cloned and sequenced. As demonstrated previously for four other rice peroxidases (Chittoor et al. 1997), DNA blot analyses with two $\mathrm{PO}-\mathrm{Cl}$-specific probes indicate that the $\mathrm{PO}$ $C 1$ gene exists as a single copy in the rice cultivar IRBB10. The PO-C1 protein shares a high level of similarity with other pathogen-induced rice peroxidases (Chittoor et al. 1997) and other monocotyledons such as wheat and barley (Rebmann et al. 1991), suggesting that they share a common ancestor gene.
$P O-C l$ was not detected in a previous study designed to investigate pathogen-inducible peroxidases from a rice cDNA library constructed at $12 \mathrm{~h}$ postinoculation with an avirulent strain of X. oryzae pv. oryzae (Chittoor et al. 1997). However, two other pathogen-induced peroxidases, POX8.1 and POX22.3, were identified, and enhanced expression of these enzymes was first detected at $6 \mathrm{~h}$ postinoculation during the incompatible interactions (Chittoor et al. 1997). Expression of these peroxidases during compatible interactions was reduced or delayed, and only POX8.1 showed brief enhanced expression after wounding. Initial induction of $\mathrm{PO}-\mathrm{Cl}$ is delayed comparable to POX8.1 and POX22.3 (12 to $18 \mathrm{~h}$ versus 6 to $12 \mathrm{~h}$ ), but it is induced only during pathogen interactions. The detection of the $\mathrm{PO}-\mathrm{Cl}$ transcript during incompatible interactions is consistent with the detection of $\mathrm{PO}-\mathrm{C} 1$ protein by immunogold labeling (12 h) and with the thickening of the xylem vessel walls $(48 \mathrm{~h})$. Thus, our data are consistent with a role for $\mathrm{PO}-\mathrm{C} 1$ in the defense response of rice against $X$. oryzae pv. oryzae. Whether or not PO-C1 acts alone or in concert with other peroxidases, particularly those that are induced earlier in incompatible interactions, to cause the wall thickening is not known.

Bestwick and associates $(1997,1998)$ reported peroxidase activity and the deposition of cerium perhydroxide precipitates at the site of adhesion of Pseudomonas syringae pv. phaseolicola to lettuce cell walls. $\mathrm{H}_{2} \mathrm{O}_{2}$ is known to accumulate in lignifying cell walls (Czaninski et al. 1993) and to potentially have antimicrobial activity (Lamb and Dixon 1997). We have also observed deposition of cerium perhydroxide precipitates in $X$. oryzae pv. oryzae interactions (E. Hilaire and J. E. Leach, unpublished data). However, as it is induced relatively late in the defense interaction, $\mathrm{PO}-\mathrm{C} 1$ is unlikely to be involved in the very early accumulation of hydrogen peroxide.

Nicholson and Hammerschmidt (1992) have proposed that secretion of pathogenesis-induced peroxidases into intercellular spaces is involved in controlling the invasion of pathogens, either by the production of reactive oxygen species that are toxic to pathogens or by the construction of physical barriers that would impede a pathogen's ability to penetrate the plant cell (Benhamou 1995; Ride 1983; Tiburzy and Reisener 1990). Because PO-C1 utilizes the lignin precursor coniferyl alcohol as a substrate (Reimers et al. 1992), accumulates in cell walls during lignification (Reimers and Leach 1991), and is associated with secondary xylem wall thickening (Table 1), it is a good candidate for a lignin peroxidase. Lignin and other phenolic polymers are polymerized into plant cell walls forming physical barriers (Benhamou 1995; Ride 1983; Tiburzy and Reisener 1990). Since plant bacterial pathogens such as $X$. oryzae pv. oryzae do not penetrate host cells, we had previously proposed that cell wall lignification would not be an effective way of preventing bacterial spread unless lignified materials would block movement between the epithem and xylem vessels (Reimers et al. 1992; Young et al. 1995). In this study, we show that thickening of the xylem secondary wall decreases the extent to which the pit membrane is exposed to bacterial cells, reducing their access to the xylem parenchyma cells. Thus, lignified walls in xylem vessels may provide a barrier to the transfer of materials essential to virulence or avirulence from bacterial pathogens to plant cells. 
Mature rice plants, which are less susceptible to $X$. oryzae pv. oryzae (Mew 1987), also exhibit thickened xylem secondary walls with small pit diameters. In addition to activation of the defense response, pathogenic colonization of the xylem vessel may require access by the bacteria to living xylem parenchyma cells; perhaps contact is required to initiate nutrient leakage into the xylem lumen. Some $X$. oryzae pv. oryzae avirulence genes are known to contribute to pathogen virulence (Bai et al. 2000), and the products of these genes are thought to function inside the plant cell (Zhu et al. 1999). Thus, reduction of access to living cells by thickened secondary walls could be one reason for enhanced resistance in mature rice plants. Because expression of the $\mathrm{PO}-\mathrm{Cl}$ gene was not observed in untreated mature leaves and was only observed during interactions with the bacteria, $\mathrm{PO}-\mathrm{C} 1$ may not be involved in the developmental thickening of xylem parenchyma secondary walls. However, our assays may not have detected a very low level of $\mathrm{PO}-\mathrm{Cl}$ expression that could contribute to wall thickening in aging plants.

Finally, the lignin biosynthetic process, which is enhanced during the rapid xylem secondary wall deposition that occurs during the defense response, could also be an important component of the defense response against bacteria. Toxic phenolic compounds (Horino and Kaku 1989; Venere 1980), phenolic free radicals, and activated oxygen (Elstner 1982), all of which are associated with lignification, may inhibit or kill bacteria. Since peroxidase catalyzes the polymerization of lignin, PO-C1 may contribute to the defense response as a consequence of its function in lignin biosynthesis.

\section{MATERIALS AND METHODS}

\section{Plant and bacterial culture.}

Rice (Oryza sativa L.) cultivar IR24 is susceptible to the $X$. oryzae pv. oryzae strains used in this study. Cultivar IRBB10 contains the $\mathrm{Xa10}$ gene for bacterial blight resistance, is nearisogenic to 'IR24', and is resistant to X. oryzae pv. oryzae PXO99 ${ }^{\mathrm{A}}(\mathrm{pBUavrXa10})$ and $\mathrm{PXO} 99^{\mathrm{A}}(\mathrm{pBUavrXa10.F1),} \mathrm{which}$ contain avirulence gene avrXa10 (Young et al. 1995). 'IRBB10' is susceptible to strains $\mathrm{PXO} 99^{\mathrm{A}}(\mathrm{pHMI})$ or $\mathrm{PXO}^{\mathrm{A}}(\mathrm{pBU})$, which contain the cloning vectors pHMI and pBU (a pUFR027/ pBlueScript $\mathrm{SK}^{+}$fusion) but lack the $a v r X a 10$ gene (Young et al. 1995). Seedlings were grown in growth chambers or greenhouses as described previously (Reimers and Leach 1991).

$X$. oryzae pv. oryzae strains were maintained at $28^{\circ} \mathrm{C}$ on modified Wakimoto's medium (Karganilla et al. 1973) amended with kanamycin $(50 \mu \mathrm{g} / \mathrm{ml})$ as required. For plant inoculations, bacteria were cultured in nutrient broth (Difco Laboratories, Detroit, MI, U.S.A.) on a rotary shaker $(250 \mathrm{rpm})$ at $28^{\circ} \mathrm{C}$ and the inoculum concentration was adjusted to $5 \times 10^{9} \mathrm{CFU} / \mathrm{ml}$ (Reimers and Leach 1991). The first fully expanded leaf of 12-day-old rice plants was inoculated by infiltration into multiple sites (Reimers and Leach 1991; Reimers et al. 1992) for use in RNA extraction or TEM. Bacteria were inoculated by the leaf-clipping technique (Kauffman et al. 1973) for SEM studies. Infiltrated leaves were frozen for RNA extraction or fixed for TEM at $0,6,12,18,24,36$, and $48 \mathrm{~h}$ postinoculation. For SEM, a 2 -cm section of leaf immediately below the clipped site was excised and frozen at 3 and $48 \mathrm{~h}$ after clip inoculation. Samples for SEM were also taken from leaves of 65-day-old untreated plants.

\section{Tissue preparation for electron microscopy.}

For SEM of freeze-fractured samples, rice tissue samples were immersed in liquid nitrogen, fixed in $4 \%$ paraform-

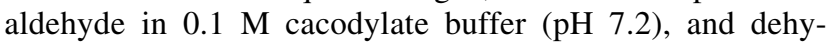
drated in $100 \%$ ethanol (Boyde 1974). After a second rinse in $100 \%$ ethanol, the samples were freeze-fractured in liquid nitrogen (Humphreys 1975). For immunolabeling of tissue for SEM, samples were probed with anti-PO-C1 antibodies, fixed as above, dehydrated in an ethanol series, and critical point-dried. The samples were mounted on specimen stubs and sputter coated with gold to a thickness of $200 \AA$ A. Specimens were observed with a Hitachi H-300/3010 scanning electron microscope (Hitachi Instruments Inc., San Jose, CA, U.S.A.).

For TEM, rice leaf material was fixed overnight in freshly prepared $4 \%$ (vol/vol) paraformaldehyde and $0.05 \%$ ( vol $/ \mathrm{vol})$ glutaraldehyde in cacodylate buffer at $4^{\circ} \mathrm{C}$. Fixed leaf tissues were dehydrated through a graded ethanol series and infiltrated in several changes of London resin White resin as described by the manufacturer (Polysciences, Inc., Warrington, PA, U.S.A.). The tissue was embedded in BEEM capsules (Taab Laboratories, Aldermaston, Berks, U.K.) by polymerization of the resin for 24 to $48 \mathrm{~h}$ at $60^{\circ} \mathrm{C}$. Ultrathin sections on parlodion-covered nickel grids were immunogoldlabeled and stained as described by Lutkenhaus and Bi (1991). The sections were examined with a Hitachi H-300 transmission electron microscope (Hitachi Instruments Inc.).

Anti-PO-C1 antibodies against the synthetic peptide MNLAMNLAPLD (Young et al. 1995) were used to detect the rice cationic peroxidase $\mathrm{PO}-\mathrm{C} 1$ in immunogold-staining studies. Antibodies were purified either by affinity chromatography using peptide bovine serum albumin (BSA) conjugates linked to Affi-gel 10 (Bio-Rad Laboratories, Hercules, CA, U.S.A.) or by eluting antibodies from peptide-BSA conjugates bound to nitrocellulose according to Smith and Fisher (1984). The antibodies were used at a dilution of the same concentration for all labeling experiments. Specificity of labeling was assessed in TEM experiments by the following controls: incubation with preimmune serum instead of primary antiserum, and competitive binding studies using anti-PO-C1 and anti-PLD $\mathrm{F}(\mathrm{ab})_{2}$ fragments as described by Young and associates (1995, 1996).

\section{Quantitation of immunogold particles in TEM and secondary cell wall thickening in SEM experiments.}

Thin sections of infected leaf tissue were analyzed at a magnification of $\times 30,000$ by TEM. For each treatment with antibodies, two grids with two sections per grid, two fields per section, and $5 \mathrm{~cm}^{2}$ or $5 \mathrm{~cm}$ per organelle per field were examined for gold particles. Each treatment consisted of two replicates. The gold particles in and around the different plant organelles were counted on prints with the aid of a $1-\mathrm{cm}^{2}$ grid. Values are reported as mean numbers \pm the standard error of the mean.

Cross sections of five rice leaves were analyzed by SEM for each treatment and for each time point. At least 10 pictures for each time point and treatment were used to obtain 30 measurements each of the short axis of the elipse of the xylem secondary wall width (relative to what is exposed in the xylem vessel) and the pit length. Values are reported as mean numbers \pm the standard error of the mean. 


\section{PO-C1 cloning.}

'IRBB10' DNA $(10 \mu \mathrm{g})$ was digested with PstI or EcoRI and then ligated in a final volume of $250 \mu$. Two sets of primers were designed according to a partial amino acid sequence of the purified PO-C1 protein (Young et al. 1995). These were 5'CGGGCGCCAGGTTCATGTCGCC 3' combined with either 5'TGCTGTCGAACAAGGGCCT3' or 5'TGAGGAACTTCGCGTCCAA3'. For inverse polymerase chain reactions (IPCR), samples contained $200 \mathrm{ng}$ of ligated 'IRBB10' DNA; 25 pmol of each primer; 50 pmol of dATP, dCTP, dGTP, and dTTP (Promega, Madison, WI, U.S.A.); 2 units of Taq DNA polymerase (Promega); and $0.1 \mathrm{M} \mathrm{MgCl}_{2}$. The I-PCR products were subcloned into the TOPOII vector (Invitrogen, Carlsbad, CA, U.S.A.) and sequenced at the Iowa State University DNA Sequencing Facility (Ames, IA, U.S.A.).

The $3^{\prime}$ UTR of $P O-C l$ was missing in the original I-PCRderived clone. To obtain this sequence, total RNA was extracted from 'IRBB10' leaves undergoing resistant interactions for $24 \mathrm{~h}$ (RNeasy Plant Mini Kit; Qiagen, Santa Clarita, CA, U.S.A.), and polyA mRNA was purified by means of an oligo(dT) column (Stratagene, La Jolla, CA, U.S.A.). The 3' UTR of $P O-C 1$ was amplified using the $3^{\prime}$ Rapid Amplification cDNA Ends Kit (Life Technologies, Gaithersburg, MD, U.S.A.), and the fragment was cloned and sequenced.

The $P O-C 1$ cDNA was identified from a pathogen-induced cDNA library constructed from RNA isolated $12 \mathrm{~h}$ after infiltration of 'IRBB10' leaves with $X$. oryzae pv. oryzae strain PXO99A(pBUavrXa10). The cDNA was synthesized from poly $(\mathrm{A})^{+}$-enriched RNA and ligated into hybrizap vector according to the manufacturer's instructions (Stratagene). DNA was packaged using the MaxPlax Lambda packaging kit (Epicentre Technologies Corporation, Madison, WI, U.S.A.). The primary library with a titer of $10^{6}$ phage per $\mu$ was amplified. Plaques were transferred to nylon membrane and screened for hybridization with the $3^{\prime}$ UTR of $\mathrm{PO}-\mathrm{Cl}$. Plaques that hybridized to $\mathrm{PO}-\mathrm{Cl}$ were purified by three rounds of replating and screening.

\section{DNA and RNA blot analyses.}

'IRBB10' DNA was isolated as described by SaghaiMaroof and associates (1984). DNA (10 $\mu \mathrm{g}$ per lane) was digested by restriction enzymes individually (EcoRI, EcoRV, HindIII, XbaI, and DraI) or in combination with others $($ NheI + XmnI, BamHI + NheI, BamHI + XmnI, HindIII + BamHI, HindIII + NheI, and HindIII +XmnI). After separation in agarose gels, the fragments were transferred to nylon membranes. The blots were prehybridized at $42^{\circ} \mathrm{C}$ with ULTRAHyb buffer (Ambion, Austin, TX, U.S.A.) and hybridized using a ${ }^{32} \mathrm{P}$-labeled probe amplified from the first intron in $\mathrm{PO}-\mathrm{Cl}$ or the $5^{\prime} \mathrm{UTR}$ of $\mathrm{PO}-\mathrm{Cl}$. After overnight hybridization, the membrane was washed twice $(15 \mathrm{~min}$ per wash) at $42^{\circ} \mathrm{C}$ in $2 \times \mathrm{SSC}(1 \times \mathrm{SSC}$ is $0.15 \mathrm{M} \mathrm{NaCl}$ plus $0.015 \mathrm{M}$ sodium citrate) and twice in $1 \times \mathrm{SSC}$.

Total RNA was extracted from frozen leaves using the RNeasy Plant Mini Kit (Qiagen). RNA (5 $\mu$ g per lane) was separated on a formaldehyde gel and then transferred to nylon membranes (Sambrook et al. 1989). The membranes were prehybridized at $65^{\circ} \mathrm{C}$ with the ULTRAHyb buffer (Ambion), hybridized overnight with the ${ }^{32} \mathrm{P}$-labeled $3^{\prime} \mathrm{UTR}$ of $\mathrm{PO}-\mathrm{Cl}$, and washed twice in $2 \times \mathrm{SSC}$ and twice in $1 \times \mathrm{SSC}\left(15 \mathrm{~min}\right.$ at $65^{\circ} \mathrm{C}$ per wash).

\section{ACKNOWLEDGMENTS}

This work was supported by USDA-NRI (94-37303-0659), NASANAG (10-0142), and the Kansas Agricultural Experiment Station (01462-J). We thank S. Lee for technical assistance, J. Foltz for artistic assistance, and J. Bai and C. J. Wu for critically reviewing the manuscript.

\section{LITERATURE CITED}

Bai, J., Choi, S.-H., Ponciano, G., Leung, H., and Leach, J. E. 2000. Xanthomonas orzyae pv. orzyae avirulence genes contribute differently and specifically to pathogen aggressiveness. Mol. Plant-Microbe Interact. 13:1322-1329.

Beckman, C. H., Morgham, A. T., and Mueller, W. C. 1991. Enlargement and vacuolization of the cytoplasm in contact cells resistant and susceptible tomato plants following inoculation with Fusarium oxysporum f. sp. lycopersici. Physiol. Mol. Plant Pathol. 38:433-442.

Benhamou, N. 1995. Ultrastructural and cytochemical aspects of the response of eggplant parenchyma cells in direct contact with Verticillium-infected xylem vessels. Physiol. Mol. Plant Pathol. 46:321-338.

Bestwick, C. S., Brown, I. R., Bennet, M. H. R., and Mansfield, J. W. 1997. Localization of hydrogen peroxide accumulation during the hypersensitive reaction of lettuce cells to Pseudomonas syringae pv. phaseolica. Plant Cell 9:209-221.

Bestwick, C. S., Brown, I. R., and Mansfield, J. W. 1998. Localized changes in peroxidase activity accompany hydrogen peroxide generation during the development of a nonhost hypersensitive reaction in lettuce. Plant Physiol. 118:1067-1078.

Boyde, A. 1974. Freezing, freeze-fracturing, and freeze-drying in biological specimen preparation for the SEM. Pages 1043-1046 in: SEM/1974. IIT Research Institute, Chicago.

Bradley, D. J., Kjellbom, P., and Lamb, C. J. 1992. Elicitor- and woundinduced oxidative cross-linking of a plant cell wall proline-rich protein: A novel, rapid defense response. Cell 70:21-30.

Chittoor, J. M., Leach, J. E., and White, F. F. 1997. Differential induction of a peroxidase gene family during infection of rice by Xanthomonas oryzae pv. oryzae. Mol. Plant-Microbe Interact. 10:861-871.

Chittoor, J. M., Leach, J. E., and White, F. F. 1999. Induction of peroxides during defense against pathogens. Pages 171-193 in: Pathogenesis-Related Proteins in Plants. S. K. Datta and S. Muthukrishnan, eds. CRC Press, New York.

Czaninski, Y., Sachot, R. M., and Catesson, A. M. 1993. Cytochemical localization of hydrogen peroxide in lignifying cell walls. Ann. Bot. 72:547-550.

Elstner, E. F. 1982. Oxygen activation and oxygen toxicity. Annu. Rev. Plant Physiol. 33:73-96.

Espelie, K. E., Franceschi, V. R., and Kolattukudy, P. E. 1986. Immunocytochemical localization and time course of appearance of an anionic peroxidase associated with suberization in wound-healing potato tuber tissue. Plant Physiol. 87:487-492.

Fry, S. C. 1986. Cross-linking of matrix polymers in the growing walls of angiosperms. Annu. Rev. Plant Physiol. 37:165-186.

Galan, J. E., and Collmer, A. 1999. Type III secretion machines: Bacterial devices for protein delivery into host cells. Science 284:13221328.

Goodman, R. N., Kiraly, Z., and Wood, K. R. 1986. The biochemistry and physiology of plant disease. University of Missouri Press, Columbia, MO, U.S.A.

Guo, A., Reimers, P. J., and Leach, J. E. 1993. Effect of light on incompatible interactions between Xanthomonas oryzae pv. oryzae and rice. Physiol. Mol. Plant Pathol. 42:413-425.

Hammerschmidt, R., and Kuc, J. 1982. Lignification as a mechanism for induced systemic resistance in cucumber. Physiol. Mol. Plant Pathol. 20:61-71.

Horino, O. 1976. Induction of bacterial leaf blight resistance by incompatible strains of Xanthomonas orzyae in rice. Pages 43-55 in: Biochemistry and Cytology of Plant Parasite Interactions. K. Tomiyama, J. M. Daly, I. Uritani, H. Oku, and S. Ouchi, eds. Kodansha, Tokyo.

Horino, O. 1981. Ultrastructural histopathology of rice leaves infected with Xanthomonas campestris pv. oryzae on Kogyok group rice varieties with different levels of resistance at the seedling stage. Ann. Phytopathol. Soc. Jpn. 47:501-509. 
Horino, O., and Kaku, H. 1989. Defense mechanisms of rice against bacterial blight caused by Xanthomonas oryzae pv. oryzae. Pages 135152 in: Bacterial Blight in Rice. International Rice Research Institute, Los Baños, Philippines.

Humphreys, W. J. 1975. Drying soft biological tissue for scanning electron microscopy. Pages 707-714 in: SEM/1974. IIT Research Institute, Chicago.

Iiyama, K., Lamb, T. B.-T., and Stone, B. A. 1994. Covalent cross links in the cell wall. Plant Physiol. 104:315-320.

Ikegawa, T., Mayama, S., Nakayashiki, H., and Kato, H. 1996. Accumulation of diferulic acid during the hypersensitive response of oat leaves to Puccinia coronata f. sp. avenae and its role in the resistance of oat tissues to cell wall degrading enzymes. Physiol. Mol. Plant Pathol. 48:245-255.

Karganilla, A., Paris-Natural, M., and Ou, S. H. 1973. A comparative study of culture media for Xanthomonas oryzae. Philipp. Agric. 57: 141-152.

Kauffman, H. E., Reddy, A. P. K., Hsiek, S. P. V., and Marca, S. D. 1973. An improved technique for evaluating resistance of race varieties to Xanthomonas oryzae. Plant Dis. Rep. 57:537-541.

Kristensen, B. K., Bloch, H., and Rasmussen, S. K. 1999. Barley coleoptile peroxidases: Purification, molecular cloning, and induction by pathogens. Plant Physiol. 120:501-512.

Lamb, C., and Dixon, R. A. 1997. The oxidative burst in plant disease resistance. Annu. Rev. Physiol. Plant Mol. Biol. 48:251-275.

Lutkenhaus, J., and Bi, E. 1991. FtsZ ring structure associated with division in Escherichia coli. Nature 354:161-164.

Martinez, C., Baccou, J., Bresson, E., Baissac, Y., Daniel, J., Jalloul, A., Montillet, J., Geiger, J., Assigbetsé, K., and Nicole, M. 2000. Salicylic acid mediated by the oxidative burst is a key molecule in local and systemic responses of cotton challenged by an avirulent race of Xanthomonas campestris pv. malvacearum. Plant Physiol. 122:757-766.

Mew, T. W. 1987. Current status and future prospects of research on bacterial blight of rice. Annu. Rev. Phytopathol. 25:359-382.

Moerschbacher, B. 1992. Plant peroxidases: Involvement in response to pathogens. Pages 91-99 in: Plant Peroxidases 1980-1990: Topics and Detailed Literature on Molecular, Biochemical, and Physiological Aspects. C. Penel, T. Gaspar, and H. Greppin, eds. University of Geneva, Geneva, Switzerland.

Mohan, R., and Kolattukudy, P. E. 1990. Differential activation of expression of a suberization-associated anionic peroxidase gene in nearisogenic resistance and susceptible tomato lines by elicitors of Verticillium albo-atrum. Plant Physiol. 92:276-280.

Mueller, W. C., Morgham, A. T., and Roberts, E. M. 1994. Immunocytochemical localization of callose in the vascular tissue of tomato and cotton plants infected by Fusarium oxysporum. Can. J. Bot. 72:505509.

Nicholson, R. L., and Hammerschmidt, R. 1992. Phenolic compounds and their role in disease resistance. Annu. Rev. Phytopathol. 30:369-389.

Rebmann, G., Hertig, C., Bull, J., Mauch, F., and Dudler, R. 1991. Cloning and sequencing of cDNAs encoding a pathogen-induced putative peroxidase of wheat (Triticum aestivum L.). Plant Mol. Biol. 16(2): 329-331.

Reimers, P. J., and Leach, J. E. 1991. Race-specific resistance to Xanthomonas oryzae pv. oryzae conferred by bacterial blight resistance gene $\mathrm{Xa}-10$ in rice (Oryza sativa) involves accumulation of a lignin-like substance in host tissues. Physiol. Mol. Plant Pathol. 38:39-55.

Reimers, P. J., Guo, A., and Leach, J. E. 1992. Increased activity of a cationic peroxidase associated with incompatible interactions between Xanthomonas oryzae pv. oryzae and rice (Oryza sativa). Plant Physiol. 99:1044-1050.

Ride, J. P. 1983. Cell walls and other structural barriers in defense. Pages 215-236 in: Biochemical Plant Pathology. J. A Callow, ed. Wiley-Interscience, New York

Saghai-Maroof, M. A., Soliman, K. M., Jorgensen, R. A., and Allard, R. W. 1984. Ribosomal DNA spacer-length polymorphisms in barley: Mendelian inheritance, chromosomal location, and population dynamics. Proc. Natl. Acad. Sci. U.S.A. 81:8014-8018.

Sambrook, J. C., Fritsch, E., and Maniatis, T. 1989. Molecular Cloning: A Laboratory Manual. Cold Spring Harbor Laboratory Press, Cold Spring Harbor, NY, U.S.A.

Sequeira, L., Gaard, G., and deZoeten, G. A. 1977. Attachment of bacteria to host cell walls: Its relation to mechanisms of induced resistance. Physiol. Plant Pathol. 10:43-50.

Shi, J., Mueller, W. C., and Beckman, C. H. 1991. Ultrastructural responses of vessel contact cells in cotton plants resistant and susceptible to infection by Fusarium oxysporum f. sp. vasinfectum. Physiol. Mol. Plant Pathol. 38:211-222.

Shi, J., Mueller, W. C., and Beckman, C. H. 1992. Vessel occlusion and secretory activities of vessel contact cells in resistant and susceptible cotton plants infected with Fusarium oxysporum f. sp. vasinfectum. Physiol. Mol. Plant Pathol. 40:133-147.

Smith, D. E., and Fisher, P. A. 1984. Identification, developmental regulation, and response to heat shock of two antigenically related forms of a major nuclear envelope protein in Drosophila embryos: Application of an improved method for affinity purification of antibodies using polypeptides immobilized on nitrocellulose blots. J. Cell Biol. 99:20-28.

Stoessl, A. 1967. The antifungal factors in barley. IV: Isolation, structure, and synthesis of the hordatines. Can. J. Chem. 45:1745-1760.

Sutherland, M. W. 1991. The generation of oxygen radicals during host plant responses to infection. Physiol. Mol. Plant Pathol. 39:79-93.

Tabei, H. 1967. Anatomical studies of rice plants affected with bacterial leaf blight. Ann. Phytopathol. Soc. Jpn. 33:12-16.

Tiburzy, R., and Reisener, H. J. 1990. Resistance of wheat to Puccinia graminis f. sp. tritici: Association of the hypersensitive reaction with the cellular accumulation of lignin-like material and callose. Physiol. Mol. Plant Pathol. 36:109-120.

Venere, R. J. 1980. Role of peroxidase in cotton resistant to bacterial blight. Plant Sci. Lett. 20:47-56.

Young, S. A., Guo, A., Guikema, J. A., White, F. F., and Leach, J. E. 1995. Rice cationic peroxidase accumulates in xylem vessels during incompatible interactions with Xanthomonas oryzae pv. oryzae. Plant Physiol. 107:1333-1341.

Young, S. A., Wang, X., and Leach, J. E. 1996. Changes in the plasma membrane distribution of rice phospholipase $\mathrm{D}$ during resistant interactions with Xanthomonas oryzae pv. oryzae. Plant Physiol. 107: 1333-1341.

Zhu, W., Yang, B., Wills, N., Johnson, L. B., and White, F. F. 1999. The $\mathrm{C}$ terminus of AvrXa10 can be replaced by the transcriptional activation domain of VP16 from the herpes simplex virus. Plant Cell 11: $1665-1674$ 